\title{
Roasted Coffee Extracts as Corrosion Inhibitors for Mild Steel in HCL Solution
}

\author{
Elaine Cesar do Carmo Assumpção de Souza ${ }^{a}$, Beatriz de Andrade Ripper ${ }^{a}$, Daniel Perrone ${ }^{a}$,
}

\author{
Eliane D'Elia ${ }^{a *}$
}

\author{
${ }^{a}$ Instituto de Química, Universidade Federal do Rio de Janeiro - UFRJ, Avenida Athos da Silveira \\ Ramos, 149, Centro de Tecnologia, Bloco A, CEP 21941-909, Cidade Universitária, Rio de Janeiro, RJ, \\ Brazil
}

Received: December 04, 2015; Revised: June 17, 2016; Accepted: August 23, 2016

\begin{abstract}
The behavior of roasted coffee extract and its isolated high molecular weight fraction have been investigated as carbon steel corrosion inhibitors in $\mathrm{HCl}$ solution by weight loss measurements, potentiodynamic polarization curves, electrochemical impedance and scanning electron microscopy analysis. All results showed that the high molecular weight fraction, rich in melanoidins, present an important role in the inhibitory action of the roasted coffee extract in the acid corrosion of carbon steel.
\end{abstract}

Keywords: (A) carbon steel, (B) EIS, (B) polarization, (B) SEM, (C) acid corrosion.

\section{Introduction}

The acid solutions are widely used in industry for various purposes, such as acid pickling, acidification of petroleum wells, among others ${ }^{1}$. Organic compounds containing $\mathrm{N}$, $\mathrm{O}$ and $\mathrm{S}$ atoms are considered to be effective corrosion inhibitors. The effectiveness of organic inhibitors depends on the nature and the condition of the metallic surface, the chemical composition and structure of the inhibitor. A bond can be formed between the electron pair and/or the $\pi$-electron cloud of the donor atoms and the metal surface, thereby reducing corrosive attack in acidic media. Although many of these compounds have high inhibition efficiencies, several have undesirable side effects, even at very low concentrations, due to their toxicity to humans, deleterious environmental effects, and high costs ${ }^{2}$.

In recent years, interest has increased in the development and use of low-cost and eco-friendly compounds as corrosion inhibitors for mild steel ${ }^{1-18}$. Plant extracts are generally inexpensive and can be obtained through simple extraction processes. In our previous works, the effect of aqueous extracts of spent coffee grounds, garlic peels and fruit peels (mango, orange, passion fruit and cashew), grape pomace and green Yerba mate on the corrosion of carbon steel in 1 mol L ${ }^{-1} \mathrm{HCl}$ was studied ${ }^{1,14-18}$.

The chemical composition of the roasted coffee (Coffea canephora) includes caffeine $(2.4 \%, \mathrm{w} / \mathrm{w})$ and trigonelline $(0.7 \%, \mathrm{w} / \mathrm{w})$, chlorogenic acids $(3.8 \%, \mathrm{w} / \mathrm{w})$, carbohydrates $(37.3 \%, \mathrm{w} / \mathrm{w})$, pectin $(2.0 \%, \mathrm{w} / \mathrm{w})$, protein $(7.5 \%, \mathrm{w} / \mathrm{w})$, lipids $(11 \%, \mathrm{w} / \mathrm{w})$ and Maillard reaction products (melanoidins). Caffeine and chlorogenic acids (especially 5-caffeoylquinic acid) are, together with melanoidins (which represent 25\%, $\mathrm{w} / \mathrm{w}$ ), major constituents of roasted coffee and therefore could be possibly responsible for its corrosion inhibitory properties $^{19}$.

*e-mail: eliane@iq.ufrj.br
In our previous work, two aqueous spent coffee grounds extracts (from infusion and decoction process) acted as an effective corrosion inhibitor for carbon steel in $1 \mathrm{~mol} \mathrm{~L}^{-1} \mathrm{HCl}$, which was explained through an adsorption process by a chemisorption mechanism ${ }^{1}$. Still, in this study, it was shown that the isolated chlorogenic acid (5-caffeoylquinic acid) does not explain the corrosion inhibition observed for the coffee extracts ${ }^{1}$.

Roasted coffee is rich in melanoidins, which are brown, high molecular weight heterogeneous polymers that are formed when proteins, polysaccharides, sacarose and amino acids combine through the Maillard reaction at high temperatures. Melanoidins are commonly present in foods such as barley malts, bread crust, bakery products and roasted coffee ${ }^{20}$. The chemical structure of melanoidins is complex and still unknown but could be responsible for the inhibitory action of the spent coffee ground extracts observed in our previous studies $^{1,19}$. Therefore, in the present work, we isolated the high molecular weight fraction from roasted coffee grains and studied its behavior as corrosion inhibitor.

The objective of this paper is to investigate the inhibitory action of roasted coffee extract as well as its isolated high molecular weight fraction on carbon steel corrosion in acidic medium by weight-loss measurements and electrochemical techniques, as well as through surface analyses using Scanning Electron Microscopy (SEM).

\section{Experimental}

\subsection{Inhibitors preparation}

Green (unroasted) coffee beans (Coffea canephora) were obtained from a producer at Guaxupé, Minas Gerais, Brazil. Coffee beans were roasted at $220^{\circ} \mathrm{C}$ for $8 \mathrm{~min}$ in a domestic coffee roaster (iFresh Roast SR500, USA) and ground in an electric mill. 
Aqueous roasted coffee extract was obtained by infusion. Ten grams of roasted ground coffee were added in $100 \mathrm{~mL}$ of distilled water with an initial temperature of $100{ }^{\circ} \mathrm{C}$ for 60 minutes. This extract was then filtered, lyophilized, and stored at $-4{ }^{\circ} \mathrm{C}$ prior to analysis. The lyophilized extract was used as a corrosion inhibitor for carbon steel in $1 \mathrm{~mol} \mathrm{~L}^{-1}$ hydrochloric acid (Figure 1A).

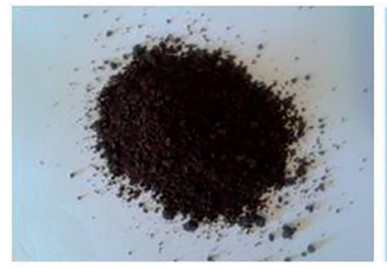

(A)

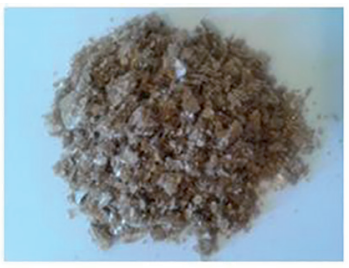

(B)
Figure 1: Aqueous roasted coffee extract (A) and its high molecular weight fraction (HMWF), rich in melanoidins (B).

The high molecular weight fraction (HMWF), rich in melanoidins, was isolated from the roasted coffee extract. The isolation of the high molecular weight fraction was performed using an ultrafiltration method. An aliquot of $45 \mathrm{~mL}$ of the roasted coffee extract was added to an ultrafiltration apparatus with $3 \mathrm{kDa}$ of cutoff (Milipore, USA) being immediately centrifuged. The fraction retained by the membrane was washed three times with water and then lyophilized and stored at $-4{ }^{\circ} \mathrm{C}$ prior to analysis (Figure 1B).

\subsection{Characterization of the inhibitors}

The high molecular weight fraction was analyzed by ${ }^{1} \mathrm{H}$ NMR (Bruker DMX-750, $500 \mathrm{MHz}$ ). Samples (10 $\mathrm{mg}$ ) were dissolved in deuterium oxide $(0.7 \mathrm{~mL})$ prior to analysis. The presaturation technique was used. The ${ }^{1} \mathrm{H}$ spectrum (Supplementary Figure 1) presented the following regions of signals: 0.5 to $1.5 \mathrm{ppm}$ (methyl and aliphatic protons of proteins); 1.5 to $2.5 \mathrm{ppm}$ (methylene protons of the cyclohexane ring of quinic acid); 3.0 to $5.0 \mathrm{ppm}$ (protons alpha to hydroxyl groups of carbohydrates, such as arabinogalactans, galactomannans, quinic acid and others); $5.3 \mathrm{ppm}$ (anomeric proton of carbohydrates); doublets with large coupling constant $(J=16.4 \mathrm{~Hz})$ at 6.5 and $7.7 \mathrm{ppm}$ (olefinic protons in trans configuration of the cinnamic moiety of chlorogenic acids); 6.8 and $7.2 \mathrm{ppm}$ (benzene rings of chlorogenic acids). Therefore, the high molecular weight fraction, rich in melanoidins, is mainly composed of modified polysaccharides and proteins.

\subsection{Electrochemical procedure}

Working electrodes were prepared from steel specimens with the following composition (wt.\%): C: 0.18, P: 0.04, S: $0.05, \mathrm{Mn}: 0.30, \mathrm{Si}$ : trace and Fe: balance. The electrodes were prepared by embedding the steel rods in epoxy resin and exposing a surface area of $1 \mathrm{~cm}^{2}$ to the electrolyte. Prior to each measurement, the sample surfaces were abraded with 100, 320, 400, 600, 1200 and 2000 grade emery paper, washed with double-distilled water, degreased with acetone and dried in warm air.

All electrochemical measurements were conducted in a thermostated conventional three-electrode Pyrex cell. A saturated calomel electrode (SCE) and a large-area platinum wire were used as the reference and auxiliary electrodes, respectively. The electrolyte was a $1 \mathrm{~mol} \mathrm{~L}^{-1} \mathrm{HCl}$ solution prepared from $37 \% \mathrm{HCl}$ (purchased from Merck Co. Darmstadt -Germany) and double distilled water. All experiments were carried out in $100 \mathrm{~mL}$ of non-stirred and naturally aerated electrolyte maintained at $25^{\circ} \mathrm{C}$.

In all experiments, the carbon steel electrode was allowed to reach its stable open-circuit potential (OCP), which occurred after $1 \mathrm{~h}$. Electrochemical impedance measurements were performed over a frequency range of $100 \mathrm{kHz}$ to $10 \mathrm{mHz}$ at the stable open-circuit potential with an AC wave of $10 \mathrm{mV}$ (rms). Potentiodynamic anodic and cathodic polarization curves were performed using a scan rate equal to $1 \mathrm{mV}$ $\mathrm{s}^{-1}$ from $-300 \mathrm{mV}$ up to $+300 \mathrm{mV}$ in relation to the stable open-circuit corrosion potential. The polarization curves were also obtained after $1 \mathrm{~h}$ in the open-circuit potential.

The electrochemical experiments were performed using an Autolab PGSTAT $128 \mathrm{~N}$ potentiostat/galvanostat, controlled by GPES 4.9 electrochemical software from Metrohm Autolab (The Netherlands). The inhibition efficiency ( $\mathrm{n} \%$ ) was calculated from potentiodynamic polarization curves and electrochemical impedance diagrams as follows:

$$
n \%=\frac{j_{\text {corr }, o}-j_{\text {corr }}}{j_{\text {corr }, o}} \times 100
$$

where $j_{\text {corr }, 0}$ is the corrosion current density in the absence of the inhibitor and $j_{\text {corr }}$ is the corrosion current density in the presence of the inhibitor obtained from Tafel plots.

$$
n \%=\frac{R_{c t}-R_{c t, o}}{R_{c t}} \times 100
$$

where $R_{\mathrm{ct}, 0}$ is the charge-transfer resistance in the absence of the inhibitor and $R_{\mathrm{ct}}$ is the charge-transfer resistance in the presence of the inhibitor obtained from the electrochemical impedance diagrams.

\subsection{Weight loss experiment}

C-steel specimens with the same composition used in the electrochemical measurements and dimensions of $3.0 \mathrm{~cm} \mathrm{x}$ $2.0 \mathrm{~cm} \times 0.15 \mathrm{~cm}$ were abraded with 100 grade emery paper, sandblasted, washed with double-distilled water, degreased with acetone, and dried in air. Triplicate specimens were 
immersed in the acid test solutions for 6, 24 and $48 \mathrm{~h}$ at room temperature in the absence and presence of the inhibitors at the following concentrations: 50, 100, 200, 300, 400 and 1000 $\mathrm{mg} \mathrm{L}^{-1}$. The temperature was controlled using an aqueous thermostat. The specimens were removed, rinsed with water and acetone, dried in warm air and stored in a desiccator. Weight loss was determined by gravimetric tests using an analytical balance (BIOPRECISA, model FA2104N) with a precision of $0.1 \mathrm{mg}$. The inhibition efficiency $(n \%)$ was obtained using the following equation:

$$
n \%=\frac{W_{O}-W}{W_{O}} \times 100
$$

where $\mathrm{W}_{0}$ and $\mathrm{W}$ are the corrosion rate which were present in $\left(\mathrm{g} \mathrm{cm}^{-2} \mathrm{~h}^{-1}\right)$ and in millimeters penetration per year $(\mathrm{mm} / \mathrm{y})$ in the absence (blank) and presence of the extract, respectively.

$$
W(m p y)=\frac{K M}{A t \mathrm{p}}
$$

where $\mathrm{K}$ is a constant $\left(8.76 \times 10^{4}\right), \mathrm{M}$ is the weight loss in grams, $\mathrm{A}$ is the specimen area in $\mathrm{cm}^{2}, \mathrm{t}$ is time in hour and $\rho$ is the specific mass of carbon steel (7.86 $\left.\mathrm{g} \mathrm{cm}^{-3}\right)$.

Weight loss measurements using 100, 200 and 400 $\mathrm{mg} \mathrm{L}^{-1}$ of 5-caffeoylquinic acid and caffeine were also performed for $24 \mathrm{~h}$ immersion at room temperature.

The temperature effects on the corrosion rate of steel coupons in $1 \mathrm{~mol} \mathrm{~L}^{-1} \mathrm{HCl}$ were examined. This experiment was performed in the absence and presence of $400 \mathrm{mg}$ $\mathrm{L}^{-1}$ of the roasted coffee extract and its isolated high molecular weight fraction with an immersion period of $2 \mathrm{~h}$ at $35,45,55$ and $65^{\circ} \mathrm{C}$.

In the present study, each experiment was repeated three times under the same conditions, and the relative differences between replicate experiments were found to be smaller than $3 \%$, indicating good reproducibility. The average of the three replicated values was used for further processing of the data.

The weight loss measurements were obtained according to ASTM G31-72, which is the standard methodology for this technique in the laboratory ${ }^{21}$.

\subsection{Surface analysis}

The specimens used for surface morphology examination were immersed in $1 \mathrm{~mol} \mathrm{~L}^{-1} \mathrm{HCl}$ in the absence (blank) and presence of 50 and $400 \mathrm{mg} \mathrm{L}^{-1}$ of each inhibitor at room temperature for $2 \mathrm{~h}$. The analysis was performed using a FEI Quanta 400 scanning electron microscope with an accelerating voltage of $20 \mathrm{kV}$.

\section{Results and Discussion}

\subsection{Electrochemical experiments}

\subsubsection{Potentiodynamic polarization curves}

Figure 2 presents the potentiodynamic polarization curves of C-steel in $1 \mathrm{~mol} \mathrm{~L}^{-1} \mathrm{HCl}$ in the absence and presence of the roasted coffee extract (A) and isolated high molecular weight fraction (B) at room temperature. The electrochemical parameters, i.e., the open-circuit potential (OCP), the corrosion potential $\left(\mathrm{E}_{\text {corr }}\right)$, the corrosion current density $\left(\mathrm{j}_{\text {corr }}\right)$, and the anodic $\left(\beta_{\mathrm{a}}\right)$ and cathodic $\left(\beta_{\mathrm{c}}\right)$ Tafel constants, shown in Table 1 , were collected from the Tafel plots.

It can be seen from the polarization curves that in the presence of the inhibitors (Figures 2A and 2B) there is a decrease in anodic and cathodic current densities, predominantly in the cathodic branch for both, which shows the inhibitory effect of these extracts. Table 1 shows that both the open circuit potential (OCP) and the corrosion potential $\left(\mathrm{E}_{\text {corr }}\right)$, derived from Tafel plots, present a cathodic shift with respect to the blank with maximum shift of 37 and $47 \mathrm{mV}$ for $\mathrm{E}_{\text {corr }}$ for the roasted coffee extract and isolated high molecular weight fraction (rich in melanoidins), respectively, demonstrating that the extracts act as a mixedtype inhibitor with a predominating cathodic character ${ }^{1}$. The corrosion current density $\left(\mathrm{j}_{\text {corr }}\right)$ decreased in the presence of the inhibitors, and this decrease was more pronounced in the case of the isolated high molecular weight fraction (rich in melanoidins).

The cathodic Tafel slopes $\left(\beta_{\mathrm{c}}\right)$ did not change significantly with the addition of the inhibitors (Table 1) showing that the adsorbed inhibitor molecules did not affect the hydrogen evolution reaction, i.e., hydrogen evolution was probably decreased by the surface blocking effect. Regarding the anodic Tafel slope $\left(\beta_{\mathrm{a}}\right)$, we can note a slight increase with the extracts concentration and this result shows that the adsorbed species to the carbon steel could modify the metal dissolution process.

The calculated inhibition efficiency based on jcorr values obtained in the absence and presence of roasted coffee extract and isolated high molecular weight fraction varied from $62 \%$ to $84 \%$ and $85 \%$ to $87 \%$, in the concentration range from 50 and 30 to $1000 \mathrm{mg} \mathrm{L}^{-1}$, respectively. The inhibition efficiency of the isolated high molecular weight fraction is higher than the roasted coffee extract. Even in the presence of $30 \mathrm{mg} \mathrm{L}^{-1}$, the isolated high molecular fraction presents $85 \%$ of inhibition efficiency. These results show that the melanoidins are probably responsible for the inhibitory action of the roasted coffee extract.

This behavior is similar to the results obtained in our previous studies using the spent coffee ground extracts (from infusion and decoction processes) ${ }^{1}$. 


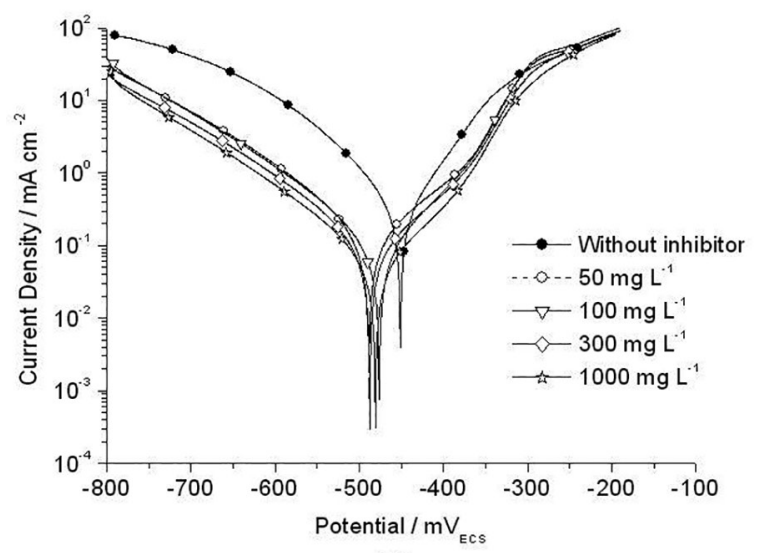

(A)

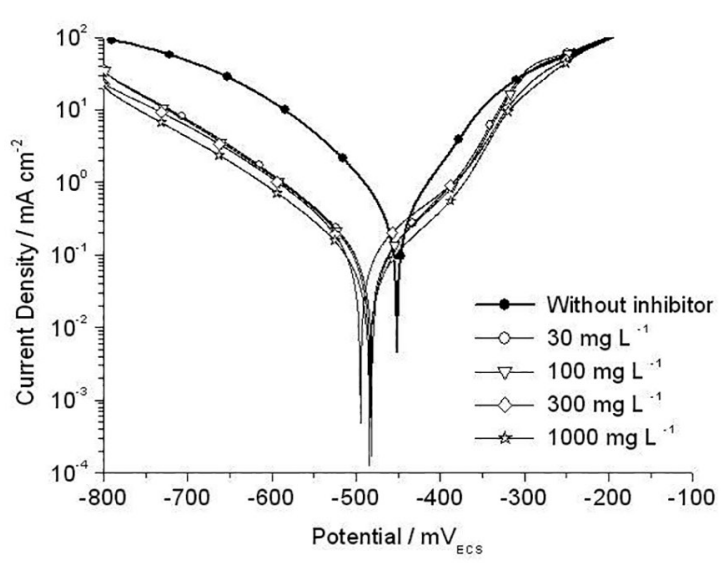

(B)

Figure 2: Polarization curves of $\mathrm{C}$-steel in $1 \mathrm{~mol} \mathrm{~L}^{-1} \mathrm{HCl}$ in the absence and presence of varying concentrations of aqueous roasted coffee extract: 50, 100, 300 and $1000 \mathrm{mg} \mathrm{L}^{-1}$ (A) and HMWF: 30, 100, 300 and $1000 \mathrm{mg} \mathrm{L}^{-1}$ (B).

Table 1: Kinetic parameters obtained from Tafel plots for C-steel in $1 \mathrm{~mol} \mathrm{~L}^{-1} \mathrm{HCl}$ in the absence and presence of aqueous roasted coffee extract and isolated high molecular weight fraction (HMWF ) at different concentrations.

\begin{tabular}{lccccccc}
\hline & $\begin{array}{c}{[\text { Inhibitor }]} \\
\left(\mathrm{mol} \mathrm{L}^{-1}\right)\end{array}$ & OCP $(\mathrm{mV} / \mathrm{SCE})$ & $\mathrm{E}_{\text {corr }}(\mathrm{mV} / \mathrm{SCE})$ & $\mathrm{j}_{\text {corr }}\left(\mathrm{mA} \mathrm{cm}^{-2}\right)$ & $\beta_{\mathrm{a}}(\mathrm{mV} / \mathrm{dec})$ & $-\beta_{\mathrm{c}}(\mathrm{mV} / \mathrm{dec})$ & $n(\%)$ \\
\hline Without inhibitor & 0 & -490 & -446 & 0.313 & 61 & 90 & -- \\
& 50 & -498 & -483 & 0.120 & 108 & 113 & 62 \\
Roasted coffee extract & 100 & -492 & -471 & 0.076 & 82 & 102 & 76 \\
& 300 & -503 & -481 & 0.075 & 96 & 107 & 76 \\
& 1000 & -495 & -473 & 0.049 & 108 & 87 & 84 \\
HMWF & 30 & -499 & -476 & 0.051 & 86 & 102 & 85 \\
& 100 & -497 & -478 & 0.059 & 90 & 101 & 82 \\
& 300 & -513 & -493 & 0.051 & 97 & 87 & 85 \\
\hline
\end{tabular}

\subsubsection{Electrochemical impedance spectroscopy (EIS)}

Figure 3 illustrates the electrochemical impedance diagrams for $\mathrm{C}$-steel in a $1 \mathrm{~mol} \mathrm{~L}^{-1} \mathrm{HCl}$ solution in the absence and presence of the roasted coffee extract (A-Nyquist plot, B and C-Bode plots) and its isolated high molecular weight fraction (D- Nyquist plot, E and F- Bode plots). Table 2 summarizes the impedance data from EIS experiments carried out in the absence and presence of increasing roasted coffee extract and its isolated high molecular weight fraction concentrations. In inhibitor-free solutions, only one depressed capacitive loop was observed and that loop can be attributed to the time constant of the charge transfer and the double layer capacitance. Such a depression is characteristic of solid electrodes and is often ascribed to dispersion effects, which have been attributed to roughness and inhomogeneities on the surface during corrosion $^{15}$. The intersection of this semicircle with the real axis at high frequencies produced a value of approximately $1.14 \Omega \mathrm{cm}^{2}$ for the ohmic resistance $\left(R_{\mathrm{s}}\right)$ of the solution. The charge-transfer resistance $\left(R_{\mathrm{ct}}\right)$ values were calculated based on the difference in impedance values at lower and higher frequencies. The double layer capacitance $\left(C_{\mathrm{d}}\right)$ was calculated using the equation below:

$$
C_{d l}=\frac{1}{2 \pi f_{\max } R_{c t}}
$$

where $f_{\max }$ is the frequency at which the imaginary component of the impedance is maximal. A $C_{\mathrm{dl}}$ value of $270 \mu \mathrm{F} \mathrm{cm}^{-2}$ was determined for the $\mathrm{C}$-steel electrode in $1 \mathrm{~mol} \mathrm{~L}{ }^{-1} \mathrm{HCl}$. The electrochemical impedance diagrams obtained in the presence of the roasted coffee extract and its isolated high molecular weight fraction also show one depressed capacitive loop. It is clearly seen that only one time constant is observed in Bode plots. Based on Table 2, it is clear that the $R_{\mathrm{ct}}$ values increased and the $C_{\mathrm{dl}}$ values decreased with the inhibitor concentration. The inhibition efficiency values $(n(\%))$ were calculated from $\mathrm{R}_{\mathrm{ct}}$ data in the absence and presence of roasted coffee extract and its isolated high molecular weight fraction being slightly higher for the isolated high molecular 

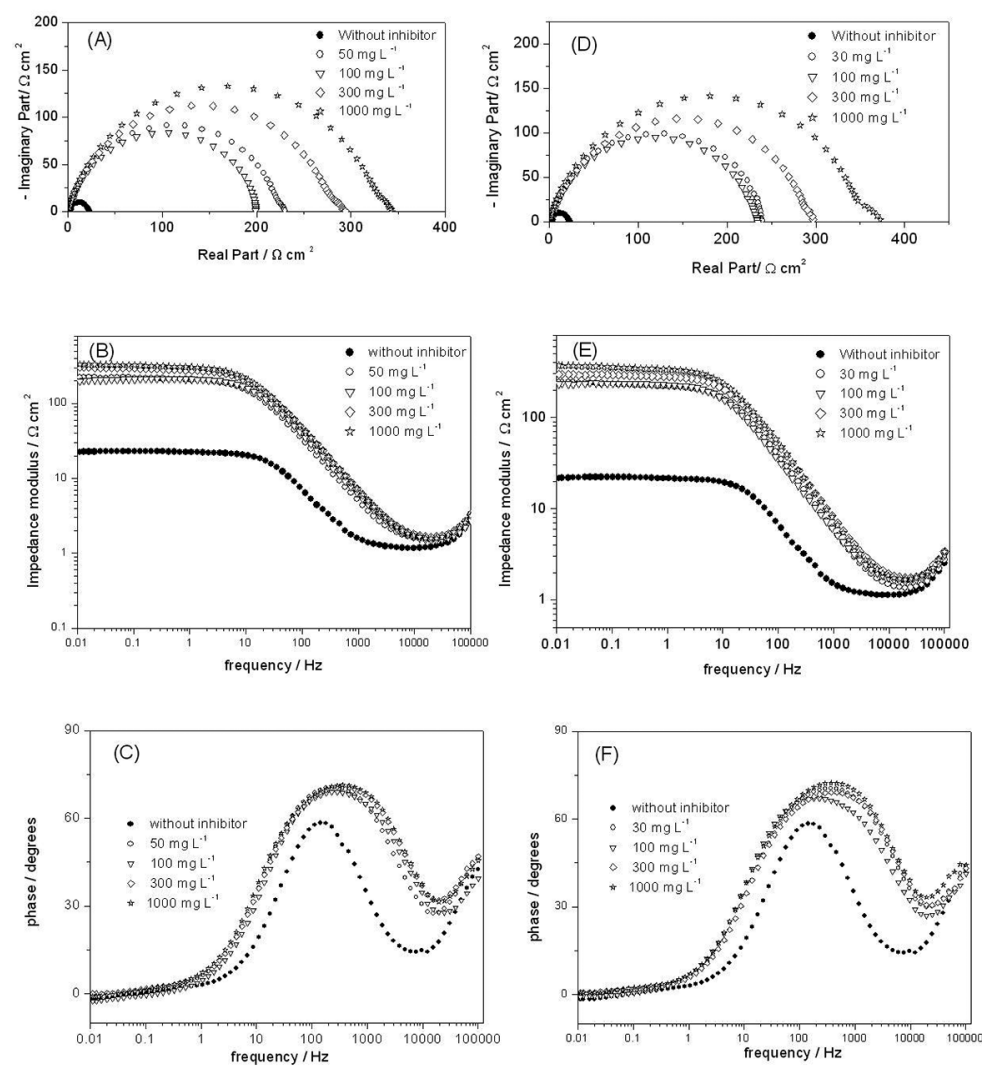

Figure 3: Electrochemical impedance diagrams of C-steel in $1 \mathrm{~mol} \mathrm{~L}^{-1} \mathrm{HCl}$ in the absence and presence of varying concentrations of aqueous roasted coffee extract: 50, 100, 300 and $1000 \mathrm{mg} \mathrm{L}^{-1}$ (A, B and C) and HMWF: 30, 100, 300 and $1000 \mathrm{mg} \mathrm{L}^{-1}$ (D, E and F).

Table 2: Electrochemical parameters obtained from EIS plots for C-steel in $1 \mathrm{~mol} \mathrm{~L}^{-1} \mathrm{HCl}$ in the absence and presence of the roasted coffee extract and its isolated high molecular weight fraction (HMWF) at different concentrations.

\begin{tabular}{lccccc}
\hline & {$[$ Inhibitor $]\left(\mathrm{mg} \mathrm{L}^{-1}\right)$} & $\mathrm{R}_{\mathrm{ct}}\left(\Omega \mathrm{cm}^{2}\right)$ & $\mathrm{f}_{\max }(\mathrm{Hz})$ & $\mathrm{Cdl}(\mu \mathrm{F} \mathrm{cm}-2)$ & $n(\%)$ \\
\hline Without inhibitor & -- & 21.0 & 28.1 & 270 & - \\
Roasted coffee & 50 & 221 & 14.0 & 51.5 & 90 \\
extract & 100 & 197 & 14.0 & 57.7 & 89 \\
& 300 & 279 & 14.0 & 40.8 & 92 \\
& 1000 & 331 & 11.1 & 43.3 & 94 \\
HMWF & 30 & 239 & 11.1 & 60.0 & 91 \\
& 100 & 233 & 11.1 & 61.6 & 91 \\
& 300 & 292 & 11.1 & 49.1 & 93 \\
& 1000 & 348 & 11.1 & 41.2 & 94 \\
\hline
\end{tabular}

weight fraction. These results may be attributable to the adsorption of these molecules onto the metal/solution interface. This hypothesis is corroborated by the anodic and cathodic polarization curves results. The inhibition efficiency was $94 \%$ at the highest concentration for both inhibitors. Once again these results are very similar to those reported for spent coffee ground extracts (from infusion and decoction process) ${ }^{1}$.

\subsection{Weight loss measurements}

The results of the weight loss measurements for the corrosion of C-steel in $1 \mathrm{~mol} \mathrm{~L}^{-1} \mathrm{HCl}$ in the absence and presence of 50-1000 $\mathrm{mg} \mathrm{L}^{-1}$ of roasted coffee extract and its high molecular weight fraction (HMWF) for different immersion times $(6,24$ and $48 \mathrm{~h})$ at room temperature are provided in Table 3. In inhibitor-free solutions the uniform corrosion rate is very severe reaching $16.2 \mathrm{~mm} / \mathrm{y}$ after 48 
Table 3: C-steel weight loss data in $1 \mathrm{~mol} \mathrm{~L}^{-1} \mathrm{HCl}$ in the absence and presence of 50, 100, 200, 300, 400 and $1000 \mathrm{mg} \mathrm{L}^{-1}$ of roasted coffee extract and HMWF for the following immersion times: 6, 24 and $48 \mathrm{~h}$ at room temperature.

\begin{tabular}{|c|c|c|c|c|c|c|c|}
\hline \multirow{3}{*}{ Time h } & \multirow{3}{*}{$\begin{array}{c}\text { [inhibitor] } \\
\mathrm{mg} \mathrm{L}^{-1}\end{array}$} & \multirow{2}{*}{\multicolumn{2}{|c|}{$\begin{array}{c}\text { Roasted coffee extract } \\
\text { Wcorr }\end{array}$}} & \multirow{3}{*}{ IE (\%) } & \multicolumn{2}{|c|}{ HMWF } & \multirow{3}{*}{ IE (\%) } \\
\hline & & & & & & & \\
\hline & & $\mathrm{g} \mathrm{cm}^{-2} \mathrm{~h}^{-1}$ & $\mathrm{~mm} / \mathrm{y}$ & & $\mathrm{g} \mathrm{cm}^{-2} \mathrm{~h}^{-1}$ & $\mathrm{~mm} / \mathrm{y}$ & \\
\hline \multirow{7}{*}{6} & 0 & 0.002630 & 29.3 & -- & 0.002630 & 29.3 & -- \\
\hline & 50 & 0.000778 & 8.67 & 70 & 0.000544 & 6.06 & 79 \\
\hline & 100 & 0.000586 & 6.53 & 78 & 0.000481 & 5.36 & 82 \\
\hline & 200 & 0.000420 & 4.68 & 84 & 0.000455 & 5.07 & 83 \\
\hline & 300 & 0.000386 & 4.30 & 85 & 0.000399 & 4.45 & 85 \\
\hline & 400 & 0.000361 & 4.02 & 86 & 0.000353 & 3.93 & 87 \\
\hline & 1000 & 0.000296 & 3.30 & 89 & 0.000319 & 3.56 & 88 \\
\hline \multirow{7}{*}{24} & 0 & 0.002213 & 24.7 & -- & 0.002213 & 24.7 & -- \\
\hline & 50 & 0.000235 & 2.62 & 89 & 0,000190 & 2.12 & 91 \\
\hline & 100 & 0.000198 & 2.21 & 91 & 0.000208 & 2.32 & 91 \\
\hline & 200 & 0.000190 & 2.12 & 91 & 0.000172 & 1.92 & 92 \\
\hline & 300 & 0.000145 & 1.62 & 93 & 0.000161 & 1.79 & 93 \\
\hline & 400 & 0.000113 & 1.26 & 95 & 0.000156 & 1.74 & 93 \\
\hline & 1000 & 0.000132 & 1.47 & 94 & 0.000123 & 1.37 & 94 \\
\hline \multirow{7}{*}{48} & 0 & 0.001456 & 16.2 & -- & 0.001456 & 16.2 & -- \\
\hline & 50 & 0.000358 & 3.99 & 75 & 0.000112 & 1.25 & 92 \\
\hline & 100 & 0.000100 & 1.11 & 93 & 0.000113 & 1.26 & 92 \\
\hline & 200 & 0.000088 & 0.981 & 94 & 0.000097 & 1.08 & 93 \\
\hline & 300 & 0.000079 & 0.880 & 95 & 0.000099 & 1.10 & 93 \\
\hline & 400 & 0.000079 & 0.880 & 95 & 0.000094 & 1.05 & 94 \\
\hline & 1000 & 0.000066 & 0.736 & 96 & 0.000083 & 0.925 & 94 \\
\hline
\end{tabular}

hours of immersion. The C-steel corrosion rate (Wcorr) was greatly reduced upon the addition of the inhibitors for all immersion times, reaching $0.736 \mathrm{~mm} / \mathrm{y}$ and 0.925 $\mathrm{mm} / \mathrm{y}$ in the presence of the extract and its fraction after 48 $\mathrm{h}$ of immersion, respectively. Even these corrosion rates are relatively high, the inhibitory action of these extracts is undoubted. According to Gentil, for cheap materials, like carbon steel, the corrosion rate could be acceptable in the range of 0.225 to $1.5 \mathrm{~mm} / \mathrm{y}^{22}$. The inhibition efficiency for both inhibitors increased with the inhibitor concentration and the immersion time, reaching $96 \%$ and $94 \%$ after $48 \mathrm{~h}$ of immersion in the presence of $1000 \mathrm{mg} \mathrm{L}^{-1}$ of the roasted coffee extract and HMWF, respectively. After $6 \mathrm{~h}$ of immersion the HMWF showed inhibition efficiency slightly higher than the roasted coffee extract. It was also noted that the inhibition efficiency remained high and stable after $24 \mathrm{~h}$ of immersion. This behavior reflects the inhibitory effect of the melanoidins towards $\mathrm{C}$-steel corrosion in acidic solution. This may also indicate the important role of the melanoidins to the inhibition process of the roasted coffee extract.

The effects of temperature on the corrosion of C-steel in 1 mol L ${ }^{-1} \mathrm{HCl}$ ranging from 35 to $65^{\circ} \mathrm{C}$ after $2 \mathrm{~h}$ of immersion are presented in Table 4 . The experiments were performed in the absence and presence of $400 \mathrm{mg} \mathrm{L}^{-1}$ of roasted coffee extract and its HMWF. The corrosion rates of the steel in both free and inhibited acid media increased as temperature increased. Additionally, the inhibition efficiencies of both inhibitors increased with the temperature, from $75 \%$ to $86 \%$ for roasted coffee extract and from $74 \%$ to $86 \%$ for melanoidins in the studied temperature range.

The apparent activation energy for C-steel corrosion in free and in inhibited acid solution was determined from an Arrhenius-type plot according to equation:

$$
\log W_{\text {corr }}=\frac{-\mathrm{E}_{\mathrm{a}}}{2.303 R T}+\log A
$$

where $\mathrm{W}_{\text {corr }}$ is the corrosion rate, $\mathrm{E}_{\mathrm{a}}$ is the apparent activation energy, $\mathrm{A}$ is the frequency factor, $\mathrm{T}$ is the absolute temperature and $\mathrm{R}$ is the molar gas constant.

Arrhenius plots of $\log \mathrm{W}_{\text {corr }}$ vs. 1/T for C-steel in $1 \mathrm{~mol}$ $\mathrm{L}^{-1} \mathrm{HCl}$ in the absence and presence of $400 \mathrm{mg} \mathrm{L}^{-1}$ of roasted coffee extract and its HMWF are shown in Figure 4. The apparent activation energy obtained for the corrosion process in the acid solution free of inhibitor was $39.0 \mathrm{~kJ} \mathrm{~mol}^{-1}$ and 23.6 and $22.8 \mathrm{~kJ} \mathrm{~mol}^{-1}$ in the presence of roasted coffee extract and HMWF, respectively. It is possible to note that the energy barrier for the corrosion reaction decreased in the presence 
Table 4: C-steel weight loss data in $1 \mathrm{~mol} \mathrm{~L}^{-1} \mathrm{HCl}$ in the absence and presence of $400 \mathrm{mg} \mathrm{L}^{-1}$ of roasted coffee extract and $\mathrm{HMWF}$ at the following immersion temperatures: $35,45,55$, and $65^{\circ} \mathrm{C}$, with an immersion period of $2 \mathrm{~h}$.

\begin{tabular}{lcccccccc}
\hline & \multicolumn{2}{c}{ Blank } & \multicolumn{2}{c}{ Roasted coffee extract } & \multicolumn{3}{c}{ HMWF } \\
$\mathrm{T}\left({ }^{\circ} \mathrm{C}\right)$ & \multicolumn{2}{c}{$\mathrm{W}_{\text {corr }}$} & \multicolumn{2}{c}{$\mathrm{W}_{\text {corr }}$} & & \multicolumn{3}{c}{$\mathrm{W}_{\text {corr }}$} \\
& $\left(\mathrm{g} \mathrm{cm}^{-2} \mathrm{~h}^{-1}\right)$ & $\mathrm{mm} / \mathrm{y}$ & $\left(\mathrm{g} \mathrm{cm}^{-2} \mathrm{~h}^{-1}\right)$ & $\mathrm{mm} / \mathrm{y}$ & & $\left(\mathrm{g} \mathrm{cm}^{-2} \mathrm{~h}^{-1}\right)$ & $\mathrm{mm} / \mathrm{y}$ & $n(\%)$ \\
\hline 35 & 0.005031 & 56,1 & 0.001261 & 14.1 & 75 & 0.001283 & 14.3 & 74 \\
45 & 0.009137 & 102 & 0.001659 & 18.5 & 82 & 0.001711 & 19.1 & 81 \\
55 & 0.013038 & 145 & 0.002249 & 25.1 & 83 & 0.002203 & 24.6 & 83 \\
65 & 0.019981 & 223 & 0.002831 & 31.6 & 86 & 0.002835 & 31.6 & 86 \\
\hline
\end{tabular}

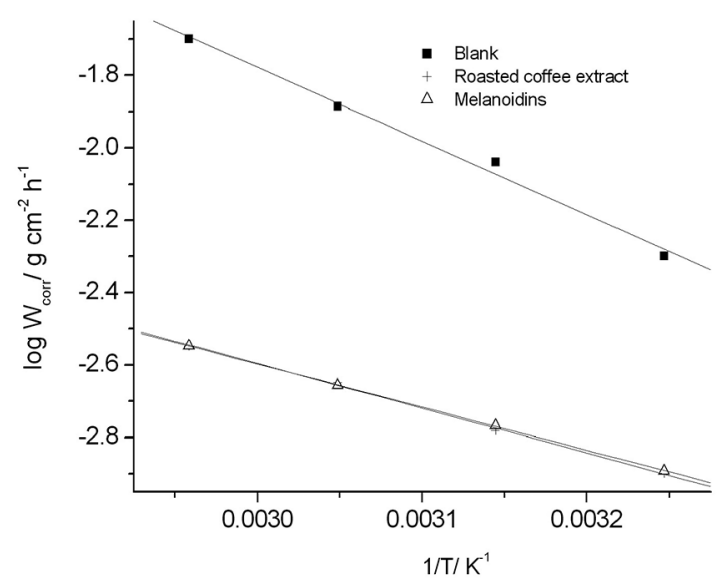

Figure 4: Arrhenius plots for the corrosion rate for C-steel in a $1 \mathrm{~mol} \mathrm{~L}^{-1} \mathrm{HCl}$ solution in the absence and presence of $400 \mathrm{mg}$ $\mathrm{L}^{-1}$ roasted coffee extract and its isolated high molecular weight fraction (HMWF).

of these inhibitors, while the inhibition efficiency increased on temperature variation (Table 5). These results could be an indication that a chemical adsorption process involving charge sharing between the melanoidins and C-steel is taking place. This behavior is similar to the results obtained in our previous studies using the spent coffee ground extract ${ }^{1}$.

Caffeine and chlorogenic acids (especially 5-caffeoylquinic acid) are, together with melanoidins (which represent 25\%, $\mathrm{w} / \mathrm{w}$ ), major constituents of roasted coffee and therefore could be possibly responsible for its corrosion inhibitory properties $^{19}$.

On the basis of these data, some weight loss measurements in $1 \mathrm{~mol} \mathrm{~L}^{-1} \mathrm{HCl}$ were performed using caffeine and 5-caffeoylquinic acid as corrosion inhibitors. The corresponding results are presented in Table 6 . The inhibition efficiency levels of both compounds were 36 and $41 \%$, respectively, at the higher concentration (400 $\mathrm{mg} \mathrm{L}^{-1}$ ). These values of inhibition efficiency are several times lower than those observed for roasted coffee extract and its HMWF, 95 and 93\%, respectively, after $24 \mathrm{~h}$ of immersion time in the presence of $400 \mathrm{mg} \mathrm{L}^{-1}$ of each inhibitor (Table 3).

To investigate if the inhibitory action was due to a synergistic action from 5-caffeoylquinic acid and caffeine,
Table 5: Linear regression parameters obtained from Arrhenius plots in $1 \mathrm{~mol} \mathrm{~L}^{-1} \mathrm{HCl}$.

\begin{tabular}{lcc}
\hline Species & Ea $\left(\mathrm{kJ} \mathrm{mol}^{-1}\right)$ & $\begin{array}{c}\text { Correlation } \\
\text { coefficients }(\mathrm{r})\end{array}$ \\
\hline Blank & 39.0 & 0.9961 \\
Roasted coffee extract & 23.6 & 0.9992 \\
HMWF & 22.8 & 0.9999 \\
\hline
\end{tabular}

other weight loss measurements were performed in the presence of both compounds (Table 7). Once more, the inhibition efficiency obtained in the presence of both compounds at $200 \mathrm{mg} \mathrm{L}^{-1}$ each was only $47 \%$ after $24 \mathrm{~h}$ of immersion time. This value is much lower than those observed for roasted coffee extract and HMWF. All these results support that the inhibitory action of the roasted coffee extract was due to the presence of melanoidins.

\subsection{Adsorption isotherm}

Organic corrosion inhibitors decrease the corrosion of metal through the adsorption on the metallic surface followed by the formation of a protective layer. The adsorption of an organic adsorbate between metal/solution interface can be represented as a substitutional adsorption process between the organic molecules in the aqueous solution $\mathrm{Org}_{\text {(soln) }}$ and the water molecules on the metallic surface $\mathrm{H}_{2} \mathrm{O}_{\text {(ads) }}$ (equation 7) .

$\mathrm{Org}_{(\text {soln })}+\mathrm{xH}_{2} \mathrm{O}_{(\mathrm{ads})} \longrightarrow \mathrm{Org}_{(\mathrm{ads})}+\mathrm{xH}_{2} \mathrm{O}_{(\text {(soln })}$

Where $\operatorname{Org}_{(\mathrm{ads})}$ are the organic molecules adsorbed on the metallic surface, $\mathrm{H}_{2} \mathrm{O}_{\text {(soln) }}$ is the water molecules in the aqueous solution and $\mathrm{x}$ is the size ratio representing the number of water molecules replaced by one molecule of organic adsorbate.

To study adsorption behavior of roasted coffee extract and melanoidins, various isotherms were used, and it was found that the Langmuir isotherm fitted better with the experimental data. The adsorption parameters obtained were recorded in Table 8. Inhibition efficiency is directly proportional to the fraction of the surface covered by adsorbed molecules $(\theta)$, which was computed from the results of the 
Table 6: Weight loss measurements for C-steel in $1 \mathrm{~mol} \mathrm{~L}^{-1} \mathrm{HCl}$ solution in the absence and presence of 5-caffeoylquinic acid (5-CQA) or caffeine, at various concentrations with $24 \mathrm{~h}$ of immersion time.

\begin{tabular}{|c|c|c|c|}
\hline \multirow{2}{*}{$\begin{array}{l}\text { 5-CQA } \\
\mathrm{mg} \mathrm{L}^{-1}\end{array}$} & \multicolumn{2}{|c|}{$\mathrm{W}_{\text {corr }}$} & \multirow{2}{*}{$\begin{array}{l}\text { IE } \\
\%\end{array}$} \\
\hline & $\mathrm{g} \mathrm{cm}^{-2} \mathrm{~h}^{-1}$ & $\mathrm{~mm} / \mathrm{y}$ & \\
\hline 0 & 0.001782 & 19.9 & - \\
\hline 100 & 0.001499 & 16.7 & 16 \\
\hline 200 & 0.001300 & 14.5 & 27 \\
\hline 400 & 0.001133 & 12.6 & 36 \\
\hline \multirow[t]{2}{*}{ Caffeine } & \multicolumn{2}{|c|}{$\mathrm{W}_{\text {corr }}$} & IE \\
\hline & $\mathrm{g} \mathrm{cm}^{-2} \mathrm{~h}^{-1}$ & mpy & $\%$ \\
\hline 0 & 0.001782 & 19.9 & - \\
\hline 100 & 0.001350 & 15.0 & 24 \\
\hline 200 & 0.001220 & 13.6 & 32 \\
\hline 400 & 0.001058 & 11.8 & 41 \\
\hline
\end{tabular}

Table 7: Weight loss measurements for C-steel in $1 \mathrm{~mol} \mathrm{~L}^{-1} \mathrm{HCl}$ solution in the absence and presence of 5-caffeoylquinic acid (5-CQA) and caffeine, at various concentrations with $24 \mathrm{~h}$ of immersion time.

\begin{tabular}{lccc}
\hline Inhibitor & \multicolumn{2}{c}{$\mathrm{W}_{\text {corr }}$} & $\mathrm{IE}$ \\
$\mathrm{mg} \mathrm{L}^{-1}$ & $\mathrm{~g} \mathrm{~cm}^{-2} \mathrm{~h}^{-1}$ & $\mathrm{~mm} / \mathrm{y}$ & $\%$ \\
\hline 0 & 0.001782 & 19.9 & - \\
$100(5-\mathrm{ACQ})+100$ (caffeine) & 0.001289 & 14.4 & 28 \\
$200(5-\mathrm{ACQ})+200$ (caffeine) & 0.000941 & 10.5 & 47 \\
\hline
\end{tabular}

weight loss study after $6 \mathrm{~h}$ of immersion time for different concentrations of both extracts (Table 3 ). The variation of $\theta$ with the inhibitor concentration specifies the adsorption isotherm that describes the system. The fit of the obtained data to the Langmuir isotherm is illustrated by plotting $\mathrm{C} / \theta$ versus $\mathrm{C}$, according to equation below:

$$
\frac{C}{\theta}=\frac{1}{K_{a d s}}+C
$$

Figure 5 displays the linear plot of the Langmuir adsorption isotherms for the melanoidins from the roasted coffee extract (Figure 5A) and from the high molecular weight fraction (Figure 5B) with a high correlation coefficient of 0.9999 and 0.9999 and a slope of 1.11 and 1.13 , respectively. This behavior suggests that the melanoidins were adsorbed onto the C-steel surface according to a Langmuir adsorption isotherm, which assumes that the inhibition occurs by monolayer adsorption at appropriate sites on the metal surface, which contains a fixed number of adsorption sites, and each site holds one adsorbate with no interaction between the adsorbate molecules ${ }^{4}$. The adsorptive equilibrium constants $\left(\mathrm{K}_{\mathrm{ads}}\right)$ for roasted coffee extract and its high molecular weight fraction at room temperature, obtained from Figures $5 \mathrm{~A}$ and $5 \mathrm{~B}$, were 0.0580 and $0.0880 \mathrm{~L} \mathrm{mg}^{-1}$, respectively. In our previous work $^{1}$, the decoction and infusion extracts from coffee grounds showed 0.0571 and $0.0645 \mathrm{~L} \mathrm{mg}^{-1}$ for the adsorptive equilibrium constants; respectively. These results indicate that melanoidins are probably responsible for the inhibitory action of the roasted coffee extract. As the chemical structure of melanoidins is complex and still unknown, the discussion of adsorption isotherm behavior in terms of thermodynamic parameters such as $\left(\Delta \mathrm{G}_{\mathrm{ads}}\right)$ is not possible.

The slight deviation of the slopes from unity (equation 8 ) could indicate the existence of interactions between the adsorbed molecules and/or that the number of phytochemical molecules occupying one active site is not unity ${ }^{4}$. On the basis of such supposition two other isotherms were plotted:

Flory-Huggins:

$$
\log (\theta / C)=\log \mathrm{K}_{\text {ads }}+\mathrm{x} \log (1-\theta)
$$

\section{Temkin:}

$$
\theta=(-2,303 / 2 \mathrm{a}) \log \mathrm{K}_{\text {ads }}+(-2,303 / 2 \mathrm{a}) \log \mathrm{C}
$$

where $\mathrm{x}$ is the number of inhibitor molecules occupying one site, or the number of water molecules replaced by one molecule of the inhibitor and $\mathrm{a}$ is the interaction parameter between the adsorbed molecules.

The values of the size parameter $\mathrm{x}$ are 2.698 and 4.977 for the aqueous roasted coffee extract and its isolated high molecular weight fraction (rich in melanoidins), respectively. These results show that one inhibitor molecule replaces more than one water molecule. Besides the interaction parameter (a) is negative in both cases, since the slopes are positive, indicating that repulsion could exist in the adsorption layer.

\subsection{Surface analysis}

Figure 6 shows a SEM micrograph of C-steel immersed for $2 \mathrm{~h}$ in $1 \mathrm{~mol} \mathrm{~L}^{-1} \mathrm{HCl}$ in the absence (Figure 6A) and presence of $400 \mathrm{mg} \mathrm{L}^{-1}$ of roasted coffee extract (Figure 6B) and its high molecular weight fraction (HMWF) (Figure 6C) at room temperature. The morphology in Figure 6A shows a rough surface, characteristic of the uniform corrosion of

Table 8: Adsorption parameters for adsorption of aqueous roasted coffee extract and its isolated high molecular weight fraction (HMWF) on carbon steel in $1 \mathrm{~mol} \mathrm{~L}^{-1} \mathrm{HCl}$ solution.

\begin{tabular}{lcccc}
\hline Isotherm & & $\mathrm{r}^{2}$ & \multicolumn{3}{c}{$\mathrm{y}=\mathrm{a}+\mathrm{bx}$} \\
\hline Adsorption & Coffee Extract & HMWF & Coffee Extract & HMWF \\
Langmuir: $\mathrm{C} / \theta$ vs. C & 0.9999 & 0.9999 & $17.16+1.111 \mathrm{x}$ & $11.39+1.128 \mathrm{x}$ \\
Temkin: $\theta$ vs. $\log \mathrm{C}$ & 0.9040 & 0.9620 & $0.4898+0.1411 \mathrm{x}$ & $0.678+0.0683 \mathrm{x}$ \\
Flory-Huggins: $\log (\theta / \mathrm{C})$ vs. $\log (1-\theta)$ & 0.9514 & 0.9561 & $-0.355+2.698 \mathrm{x}$ & $1.551+4.977 \mathrm{x}$ \\
\hline
\end{tabular}



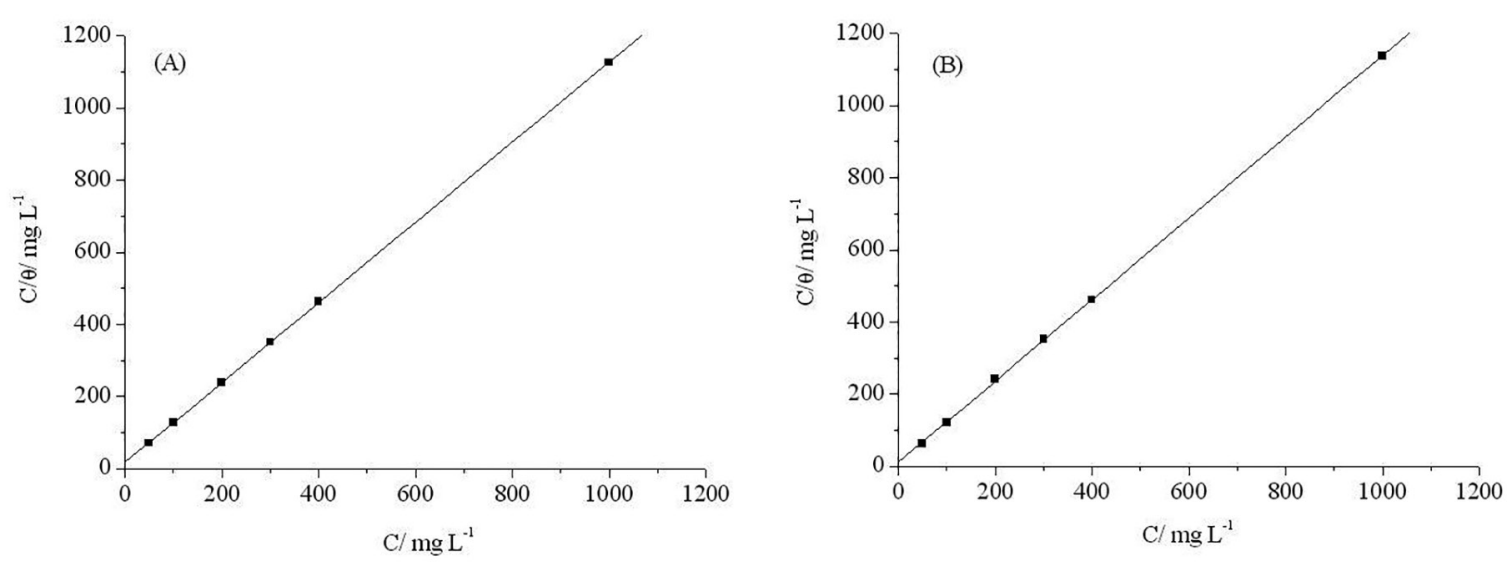

Figure 5: Langmuir adsorption isotherm of melanoidins from roasted coffee extract and its high molecular weight fraction on the C-steel surface in $1 \mathrm{~mol} \mathrm{~L}^{-1} \mathrm{HCl}$.

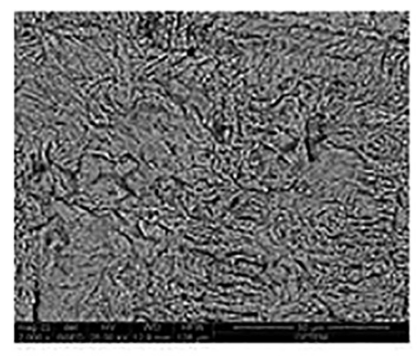

(A)

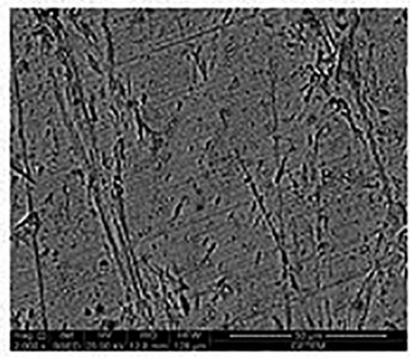

(B)

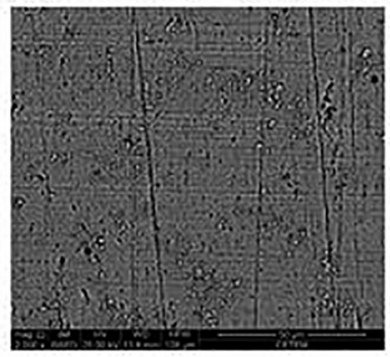

(C)

Figure 6: SEM photography $\left(2000 \mathrm{x}\right.$ ) of C-steel: immersed in $1 \mathrm{~mol} \mathrm{~L}^{-1} \mathrm{HCl}$ in the absence (a) and presence of $400 \mathrm{mg} \mathrm{L}^{-1}$ of roasted coffee extract (b) and HMWF (c).

C-steel in acid. In the presence of the extracts (Figure 6B and $6 \mathrm{C}$ ), a smooth surface can be observed, indicating that the surface was protected by the inhibitor. These results are in agreement with the electrochemical experiments and weight loss measurements, for which an excellent inhibition performance was observed.

\section{Conclusions}

Both roasted coffee extract and high molecular weight fraction (HMWF) act as effective inhibitors on C-steel in 1 mol L ${ }^{-1} \mathrm{HCl}$ solution.

1. The results obtained from the polarization curves and electrochemical impedance diagrams demonstrate that the roasted coffee extract and its isolated high molecular weight fraction act as inhibitors through an adsorption process.

2. The apparent activation energy of C-steel corrosion in $1 \mathrm{~mol} \mathrm{~L}^{-1} \mathrm{HCl}$ decreased in the presence of both inhibitors showing chemisorption of the inhibitor onto the steel surface, involving charge sharing or charge transfer from the inhibitor molecules present in both inhibitors to the C-steel surface.

3. Melanoidins are the probable components that are responsible for the inhibition action of the roasted coffee extract.

4. The SEM analysis showed that the metal surface was protected in the presence of both inhibitors. 


\section{Acknowledgements}

The authors thank Petrobras, National Council of Technological and Scientific Development (Brazil) for research fellowship support and FAPERJ for the financial support.

\section{References}

1. Torres VV, Amado RS, de Sá CF, Fernandez TL, Riehl CAS, Torres AG, et al. Inhibitory action of aqueous coffee ground extracts on the corrosion of carbon steel in $\mathrm{HCl}$ solution. Corrosion Science. 2011;53(7):2385-2392. http://dx.doi. org/10.1016/j.corsci.2011.03.021.

2. Ibrahim TH, Chehade Y, Zour MA. Corrosion Inhibition of Mild Steel using Potato Peel Extract in $2 \mathrm{M} \mathrm{HCl} \mathrm{Solution.} \mathrm{International}$ Journal of Electrochemical Science. 2011;6:6542-6556.

3. de Souza FS, Spinelli A. Caffeic acid as a green corrosion inhibitor for mild steel. Corrosion Science. 2009;51(3):642649. http://dx.doi.org/10.1016/j.corsci.2008.12.013.

4. Emran KM, Al-Ahmadi AO, Torjoman BA, Ahmed NM, Sheekh SN. Corrosion and corrosion inhibition of cast Iron in hydrochloric acid $(\mathrm{HCl}$ ) solution by cantaloupe (Cucumis melo) as green inhibitor. African Journal of Pure and Applied Chemistry. 2015;9(3):39-49. http://dx.doi.org/10.5897/AJPAC2015.0607.

5. Kamal C, Sethuraman MG. Spirulina platensis - A novel green inhibitor for acid corrosion of mild steel. Arabian Journal of Chemistry. 2012;5(2):155-161. http://dx.doi.org/10.1016/j. arabjc.2010.08.006.

6. Okafor PC, Ikpi ME, Uwah IE, Ebenso EE, Ekpe UJ, Umoren SA. Inhibitory action of Phyllanthus amarus extracts on the corrosion of mild steel in acidic media. Corrosion Science. 2008;50(8):2310-2317. http://dx.doi.org/10.1016/j. corsci.2008.05.009.

7. Singh A, Singh VK, Quraishi MA. Effect of fruit extracts of some environmentally benign green corrosion inhibitors on corrosion of mild steel in hydrochloric acid solution. Journal of Materials and Environmental Science. 2010;1(3):162-174.

8. Singh A, Ebenso EE, Quraishi MA. Corrosion Inhibition of Carbon Steel in $\mathrm{HCl}$ Solution by Some Plant Extracts. International Journal of Corrosion. 2012;2012:897430. http:// dx.doi.org/10.1155/2012/897430.

9. Al-Otaibi MS, Al-Mayouf AM, Khan M, Mousa AA, AlMazroab SA, Alkhathlan HZ. Corrosion inhibitory action of some plant extracts on the corrosion of mild steel in acidic media. Arabian Journal of Chemistry. 2014;7(3):340-346. http://dx.doi.org/10.1016/j.arabjc.2012.01.015.

10. Raja PB, Sethuraman MG. Natural products as corrosion inhibitor for metals in corrosive media - A review. Materials Letters. 2008;62(1):113-116. http://dx.doi.org/10.1016/j. matlet.2007.04.079.
11. Teixeira VM, dos Santos EC, Rezende MJC, D’Elia E. Estudo da Ação Inibidora do Extrato de Camellia sinensis na Corrosão do Aço-carbono $1020 \mathrm{em} \mathrm{HCl} 1 \mathrm{~mol} \mathrm{~L}^{-1}$. Revista Virtual de Química. 2015;7(5):1780-1794. http://dx.doi.org/1794. 10.5935/1984-6835.20150102.

12. Rubaye AYI, Abdulwahid AA, Al-Baghdadi SB, Al-Amiery AA, Kadhum AAH, Mohamad AB. Cheery Sticks Plant Extract as a Green Corrosion Inhibitor Complemented with LC-EIS/ MS Spectroscopy. International Journal of Electrochemical Science. 2015;10:8200-8209.

13. Soltani N, Khayatkashani M. Gundelia tournefortii as a Green Corrosion Inhibitor for Mild Steel in $\mathrm{HCl}$ and $\mathrm{H}_{2} \mathrm{SO}_{4}$ Solutions. International Journal of Electrochemical Science. 2015;10:4662.

14. da Rocha JC, Gomes JACP, D’Elia E. Aqueous extracts of mango and orange peel as green inhibitors for carbon steel in hydrochloric acid solution. Materials Research. 2014;17(6):15811587. http://dx.doi.org/10.1590/1516-1439.285014.

15. da Rocha JC, Gomes JACP, D'Elia E. Corrosion inhibition of carbon steel in hydrochloric acid solution by fruit peel aqueous extracts. Corrosion Science. 2010; 52(7):2341-2348. http:// dx.doi.org/10.1016/j.corsci.2010.03.033.

16. da Rocha JC, Gomes JACP, D'Elia E, Cruz APG, Cabral LMC, Torres AG, et al. Grape Pomace Extracts as Green Corrosion Inhibitors for Carbon Steel in Hydrochloric Acid Solutions. International Journal of Electrochemical Science. 2012;7:1194111956.

17. Pereira SSAA, Pêgas MM, Fernández TL, Magalhães M, Schöntag TG, Lago DC, et al. Inhibitory action of aqueous garlic peel extract on the corrosion of carbon steel in $\mathrm{HCl}$ solution. Corrosion Science. 2012;65:360-366. http://dx.doi. org/10.1016/j.corsci.2012.08.038.

18. Souza TF, Magalhães M, Torres VV, D’Elia E. Inhibitory Action of Ilex Paraguariensis Extracts on the Corrosion of Carbon Steel in HCl Solution. International Journal of Electrochemical Science. 2015;10:22-33.

19. Clarke RJ. Coffee: Roast and ground. In: Caballero B, ed. Encyclopedia of Food Sciences and Nutrition. 2nd ed. Oxford: Academic Press; 2003. p. 1487-1493.

20. Perrone D, Farah A, Donangelo CM. Influence of Coffee Roasting on the Incorporation of Phenolic Compounds into Melanoidins and Their Relationship with Antioxidant Activity of the Brew. Journal of Agricultural and Food Chemistry. 2012;60(17):4265-4275. http://dx.doi.org/ 10.1021/jf205388x.

21. ASTM International. G31-72: Standard practice for laboratory Immersion Corrosion Testing of Metals. West Conshohocken: ASTM International; 1999.

22. Gentil V. Corrosão. Rio de Janeiro: LTC; 2011. 